\title{
Blue Endorsements Matter: How the Fraternal Order of Police Contributed to Donald Trump's Victory
}

Michael Zoorob, Harvard University

ABSTRACT Conventional accounts of Donald Trump's unexpected electoral victory stress idiosyncratic events and media celebrity because most observers assume this unusual candidate won without much organized support. However, considerable evidence suggests that the support of conservative organizational networks, including police unions such as the Fraternal Order of Police (FOP), propelled Trump to victory. The FOP is both a public-sector union and a conservative, mass-membership fraternal association that was courted by the Trump campaign at a time of politically charged debates about policing. Four years before, the FOP had refused to endorse Republican candidate Mitt Romney because he opposed public-sector unionism, which provided fruitful and rare variation in interest-group behavior across electoral cycles. Using a difference-in-differences approach, I find that FOP lodge density contributed to a significant swing in vote share from Romney to Trump. Moreover, survey evidence indicates that police officers reported increased political engagement in 2016 versus 2012. Belying the notion that Trump lacked a "ground game," this research suggests that he tapped into existing organizational networks, showing their enduring importance in electoral politics.

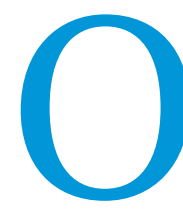

n September 15, 2016, Donald Trump won a high-profile endorsement from the Fraternal Order of Police (FOP), America's largest and oldest police union (Kamisar 2016). Following a vote of 45 state delegates, the FOP's president, Chuck Canterbury, explained that although Trump had no prior experience as an elected official, the union would enthusiastically back his campaign because "He understands and supports our priorities and our members believe he will make America safe again."

The FOP endorsement reverberated in a moment of racially charged polarization around policing. Responding to the Black Lives Matter movement and swelling anger in minority communities about police killings, many Democrats-including the party's presidential nominee Hillary Clinton-embraced new rules opposed by police unions. The July 2016 Democratic Convention featured mothers of offspring killed by police officers, and Clinton did not seek the FOP's endorsement. Meanwhile, the Republican Convention decried rising disorder in America and touted the

Michael Zoorob ${ }^{(D)}$ is a doctoral candidate in government at Harvard University. He can be reached at mzoorob@g.harvard.edu. need to back police. Trump regularly visited FOP lodges and declared that he was "on their side, 1,ooo percent"-as he did on August 18, 2016, to officers at Lodge \# 27 in North Carolina. In early September, just before the FOP decision, Trump showily invited national police leaders to Trump Tower. Throughout the campaign, Trump boasted of this endorsement at rallies and lodge visits. He continued to tout FOP support after winning, as at a White House visit in March 2017 when he explained, "I will always have your back-10o percent, like you've always had mine, and you showed that on November 8th."

Support from the FOP is potentially valuable because it claims more than 300,00o dues-paying members and 2,000 active lodges-which are concentrated in swing states including North Carolina, Ohio, and Pennsylvania (figure 1) and broadly overlap with regions of 2016 GOP gains (figure 2). In 2012, the FOP refused to endorse either party's presidential candidate because Romney opposed public-sector unions. The contrast between the FOP's non-endorsement in 2012 and its enthusiastic endorsement of Trump in 2016 provides a unique opportunity to assess the effects of backing from an organized-membership federation. Scholars typically find it difficult to see what difference, if any, 
an endorsement makes because organizations repeatedly endorse the nominee of the party to which they are closest.

Most commentators have paid little heed to organizational backing for Trump. They attribute his victory to twists such as the investigation into Clinton's emails and suggest that, as a former reality-TV star, Trump prevailed through media domination without an organized campaign. This article tests an alternative view-that is, that organized support of conservative networks, including the FOP, propelled Trump to victory. I first describe the FOP, a public-sector union and conservative, mass-membership fraternity. Then I outline several ways in which the FOP could affect electoral outcomes and present evidence that the police did have a "ground game." The FOP was an important part of that ground game in an election in which law and order was salient.

\section{THE HISTORY AND EVOLUTION OF THE FRATERNAL ORDER OF POLICE}

The FOP formed in 1915 in Pittsburgh to improve the working conditions of police officers. At that time, the FOP strongly opposed police unions. The years following the notorious 1919 Boston police strike were not conducive to organizing. Nevertheless, the FOP spread by adopting patriotic, conservative, and anti-union stances. The anti-union position softened over time. By the 1960 , the FOP had embraced collective bargaining, partly in reaction to

\section{The contrast between the FOP's non-endorsement in 2012 and its enthusiastic endorsement of Trump in 2016 provides a unique opportunity to assess the effects of backing from an organized-membershipfederation.}

officers assiduously courted by Trump exhibited heightened political engagement in 2016. Finally, I present a difference-in-differences analysis suggesting that FOP lodge density contributed to a swing from Romney to Trump.

This research demonstrates the importance of organizations in shaping electoral politics. Moreover, it enriches our understanding of the 2016 presidential contest by showing that Trump activism by other unions. In many states, FOP lodges now serve as collective-bargaining units, whereas in states that restrict collective bargaining, they are limited to fraternal and political activities (Gaines and Worrall 2011, 326). However, the law-and-order stances persisted.

FOP political activism surged during the 196os. In 1966, the FOP invited Alabama segregationist Governor George Wallace

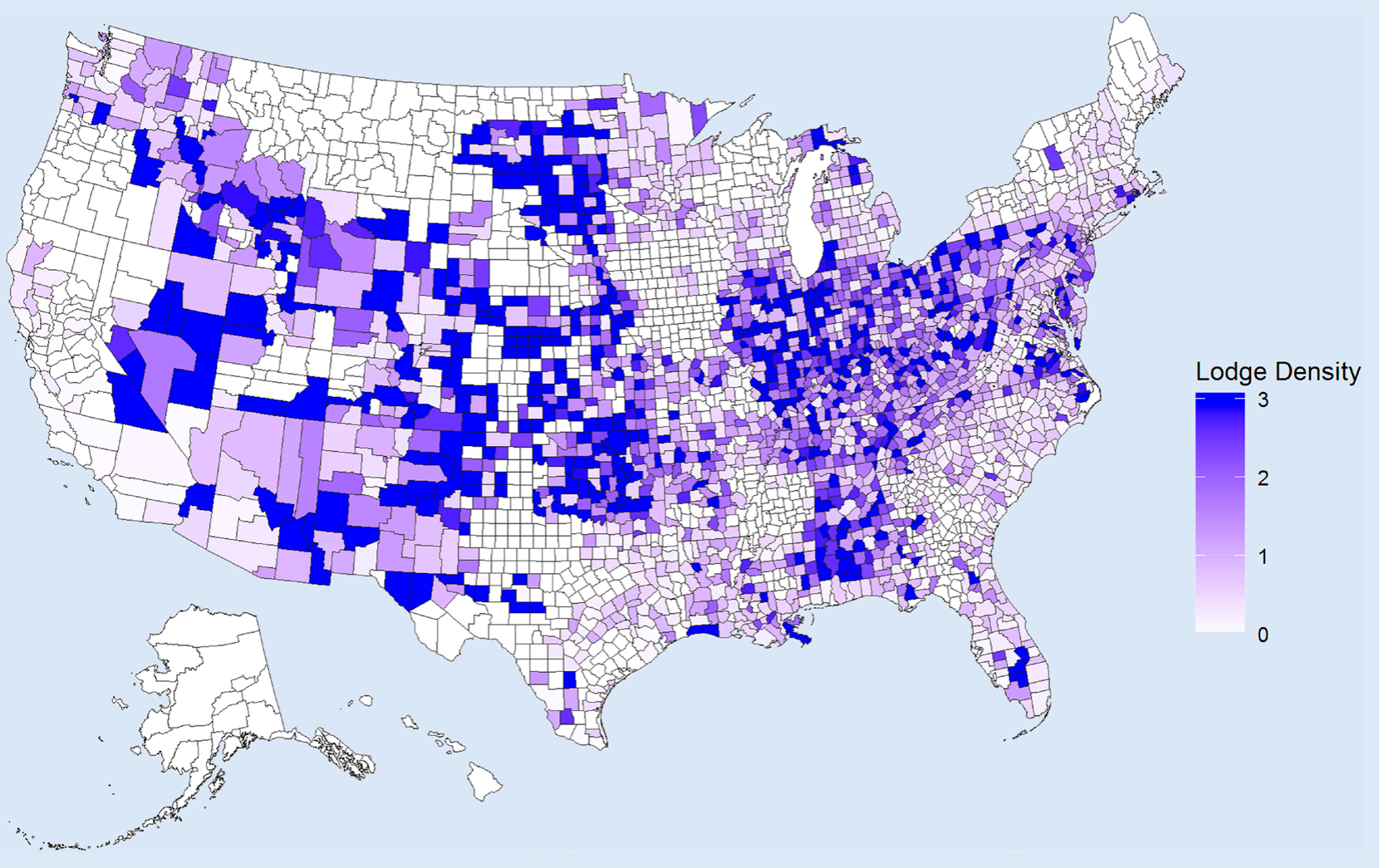


to speak at its national convention (Lesher 1994, 405). The FOP endorsed George Wallace in 1968 and Richard Nixon in 1972, and it regularly endorsed "law-and-order" candidates by 1976 (Arnesen and Lipari 2007,483 ). In 1976, the FOP secured passage of legislation compensating the families of slain officers (Walsh 1977, 306). his support for Senate Bill 5 , which would have prohibited publicsector collective bargaining (Torry 2012). One interviewee at an Ohio lodge described the general sentiment: "Some of my members have flat-out said, 'I will never again vote for someone who has an R next to their name because of what John Kasich

\section{The FOP's executive director noted exceptional enthusiasm among members, a sentiment stemming from officers'sense that they were "under siege."}

In 2004, President George W. Bush signed an FOP-backed act allowing law-enforcement officers to carry concealed firearms in all jurisdictions (Fraternal Order of Police 2013). State-level lobbying by the FOP has advanced the Police Bill of Rights, which protects officers accused of misconduct in a dozen states (Huq and McAdams 2016). More recently, the organization has backed legislation that makes the killing of a police officer a hate crime, leading to its introduction in several states and passage in Louisiana. In 2014, the FOP prevented the appointment of the proposed Department of Justice assistant attorney general for civil rights (Schreckinger 2015).

Although typically favoring Republicans in presidential races, the FOP did not endorse anyone in 2012, deeming Obama unfriendly to law enforcement and Romney critical of unions (Wheaton 2016). The contrast between 2012 and 2016 is striking: in Ohio, press reports noted the FOP's rebuke of Romney due to did" (Macgillis 2012). The Trump campaign likely recognized the FOP's unionism. His response to their questionnaire declined to take a stand on public-sector unionization, saying he would leave it to states.

Trump received votes from 39 of the 45 state delegations, well more than the two thirds required for a national endorsement. The remainder voted not to endorse anyone. The FOP's Canterbury indicated that Clinton's apathy explained her lack of support (Rentz 2016). FOP officials visited Trump Tower in August, telling reporters that they were "disappointed and shocked" by Clinton's "snub" (Swan 2016).

\section{POLICING ISSUES AS A 2016 FLASHPOINT}

Prior to the snub, the political cleavages around law enforcement had cast a shadow over the FOP and Clinton. The July Democratic Convention featured the mothers of people killed by police

\section{Figure 2}

Vote Shift from Romney to Trump (Percentage Points)

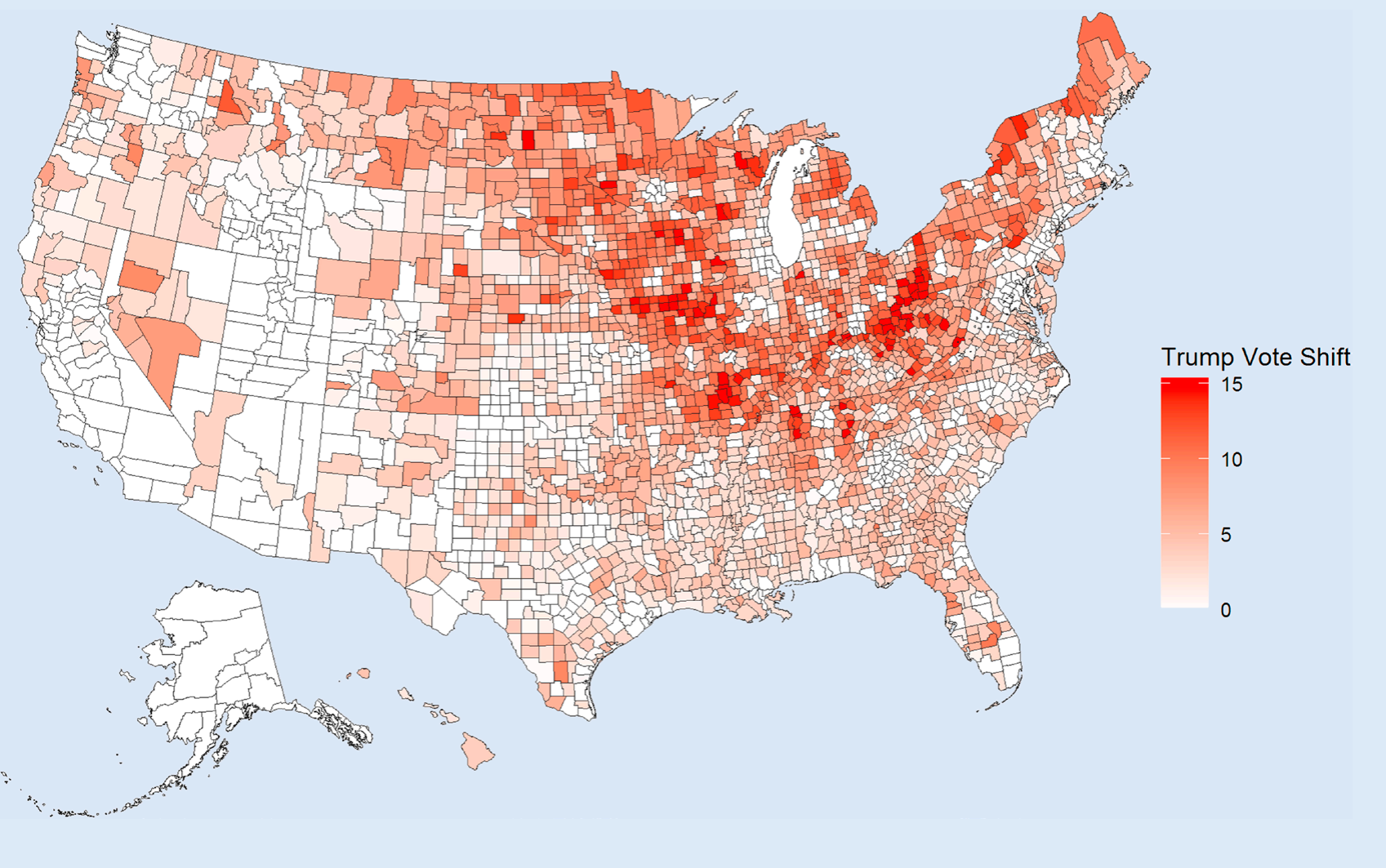


officers, a move that "shocked, angered, and saddened" the FOP, according to a viral press release (Swan 2016). Posts on the FOP's private forum also branded Barack Obama an "antipolice, antilaw and order president" (Swaine and Joseph 2016). Throughout American history, police have gravitated to right-wing, law-andorder politicians and ethnocentric groups: "The police find few segments of the body politic who appreciate their contribution to society...if they do, they find this appreciation among conservatives, and particularly the extreme right” (Lipset 1972, 288). Trump fits this mold. In one primary debate, he said, "Police are the most mistreated people in this country....We have to give power back to the police because crime is rampant" (Lee 2016a). Trump's win was thus a relief. The FOP leader in Luzerne County, Pennsylvania-traditionally a Democratic stronghold-cheered that "We, law enforcement, and the people needed this win" (Buffer 2016).

In clear contrast to Clinton, Trump actively courted the FOP. As illustrated in table 1, Trump reached out to police officersand the FOP in particular-throughout the campaign, especially in the weeks preceding the endorsement vote. On August 11, he visited FOP Lodge $\#_{5}$ in Orlando, Florida, "just to tell cops how appreciated they are." On August 16, in a speech in Wisconsin, Trump called Clinton "against the police" and billed himself as the "law-and-order" candidate. On August 18, he visited an FOP lodge in North Carolina, where he told members, "I'm on your side 1,ooo percent Trump." Before speaking at the lodge, he practiced shooting at the lodge's gun range with the county sheriff, who told reporters, "I gotta say, this man can shoot" (Associated Press 2016; Swicegood 2016). On August 21, Trump met with a sheriff in Virginia (Potomac Local 2016); the following day, he visited the FOP lodge in Akron, Ohio, sharing pictures of the meeting on Twitter (Livingston and Cottom 2016).

With the FOP endorsement came a promise to help the campaign. In the 2004 election, the Grand Lodge provided volunteers to the Bush campaign and launched a "get-out-the-vote campaign" of members and their families (Fraternal Order of Police 2004). The 2016 endorsement was equally wholehearted. The FOP's executive director noted exceptional enthusiasm among members, a sentiment stemming from officers' sense that they were "under siege." As one interviewed officer stated, "With all the anti-police rhetoric that's been going around, it was just refreshing. That's what really drew me to Donald Trump in the first place" (Kaste 2016).

Several FOP leaders echoed the national endorsement and denounced Hillary Clinton. On September 18, Canterbury explained the endorsement on National Public Radio, saying, "[Trump] wants to work on the systemic causes of high crime, and Mrs. Clinton wants to work on police reform. And reform in a profession that doesn't need to be reformed is not the answer to fight crime" (Martin 2016). In Pittsburgh, the FOP head called Clinton's choice to decline to seek the endorsement "terrifying." He praised Trump as "giving the right answers...based on the constitution" (Schneider 2016). Philadelphia's leader said Clinton "blew the police off" while Trump "cooperated" and "participated" (Giordano 2016).

The palpable enthusiasm for Trump by white law enforcement was controversial. A Clinton campaign canvasser in Cleveland reported that a police car drove down the street chanting "Trump, Trump, Trump" through its loudspeaker (Connors 2016). San Antonio cops were disciplined for wearing pro-Trump hats while in uniform (Hawkins 2016). A police union leader in Ohio was disciplined for attending a Trump rally in uniform (Gallek 2016). An Ohio sheriff published a picture of him and his team in uniform posing with Trump in a taxpayer-funded newsletter, a move criticized by the local National Association for the Advancement of Colored People (Glunt 2016). Trump also brought his support from police unions into the forefront: his campaign ran a television ad featuring Trump with uniformed Phoenix police officers, leading to a cease-and-desist letter from the city (Gardiner 2016). Trump also frequently boasted of his FOP endorsement on the campaign trail (Lee 2016b). Indeed, his support for the police may have been a defining characteristic: "Donald Trump...has been unwavering in his support of police officers" (McPhee 2016). This mutual affinity between Trump and white law enforcement reverberated throughout the media (see the appendix); by contrast, Clinton reportedly had a "prickly relationship with law enforcement" (Griffith 2016).

In contrast, leaders of black police organizations denounced the FOP's Trump endorsement (Siemaszko 2016). The FOP has a

Table 1

Key Events

July 21, 2016: FOP chastises DNC for convention program featuring mothers of victims of police killings.

July 22, 2016: FOP issues press release noting that Clinton did not respond to questionnaire.

August 5, 2016: FOP leaders meet with Trump at Trump Tower.

August 11, 2016: Trump visits FOP Lodge \#5 in Orlando, Florida, to "tell cops how appreciated they are."

August 16, 2016: Trump attends roundtable with Sheriff David Clarke and law enforcement at the War Memorial in Milwaukee, Wisconsin.

August 17, 2016: Mike Pence visits police station in Henderson, Nevada, before town hall meeting.

August 18, 2016: Trump visits FOP Lodge \#10 in Iredell County, North Carolina, and visits gun range with sheriff.

August 21, 2016: Trump has "closed-door meeting" with Sheriff David Decatur in Stafford, Virginia.

August 22, 2016: Trump meets with officers at FOP Lodge \#7 in Akron, Ohio. Posts photograph on Twitter.

September 16, 2016: The Grand Lodge endorses Trump, who received support from 39 of 45 state delegations (with six abstentions).

September 19, 2016: Trump retweets Philadelphia FOP local leader that Clinton "Blew the Police Off."

October 10, 2016: Rudy Giuliani visits Willoughby, Ohio, and accepts state's FOP endorsement on Trump's behalf.

October 24, 2016: Eric Trump visits Pennsylvania FOP Lodge for a "roundtable discussion" and accepts endorsement. 
racially fraught history, including support for George Wallace's presidential campaign and staunch opposition to black mayors, including Cleveland's Carl Stokes in the 196os. Although the organization's membership is $30 \%$ nonwhite, the seven-person national board remains all white. Many local lodges in places where the majority of officers are black are led by whites (Butler 2017). In the 1960 s and 1970s, black police organizations such as Blacks in Law Enforcement of America and Black Peace police officers, including FOP leadership, felt socially and physically threatened. With their consciousness as police "activated" by the political climate-and a clear choice between Clinton and Trump-police officers were ripe for mobilizing.

\section{IMPACT OF THE FOP ENDORSEMENT}

I tested the impact of the FOP endorsement in two ways. First, I examined individual-level political behavior of police officers in

\section{Across various specifications - and holding constant other factors that explain Trump's appeal-a significant and important association persists between the density of FOP lodges and the vote shift for Trump.}

Officers Association formed to advocate on behalf of officers overlooked by majority police organizations (Love 2017). These groups, as well as local black police organizations, denounced Trump. The black Philadelphia Guardian Civic League, representing 2,500 officers, called Trump an "outrageous bigot" (Siemaszko 2016).

The Trump administration has repeatedly advanced FOP goals. Attorney General Jeff Sessions was hailed by the FOP as a "champion of law enforcement." Canterbury gushed that "...I can say without reservation that I have never been able to testify with more optimism and enthusiasm" for a nominee. In his first months, Sessions curtailed consent-decree investigations (Hensch 2017) into police departments with systemic civil-rights violations, a long-time FOP goal (Charles 2017). The move, rebuked by civil-rights groups, was welcomed by the FOP (Whack and Gurman 2017). A subsequent announcement "effectively [ended]" federal police reform efforts (Charles 2017). In July, Sessions reversed an Obama-era restriction on civil-asset forfeitures (Delgadillo 2017). In August, he announced at the national FOP conference that Trump was rescinding the ban on transferring surplus military equipment to police (Lucas 2017).

\section{HOW ORGANIZATIONS INFLUENCE ELECTIONS}

The FOP is both a national public-sector union and a federation of fraternal associations. These features empower it to mobilize hundreds of thousands of members to shape politics (Leighley and Nagler 2007). First, as a union, the FOP has experience utilizing endorsements, volunteering members for campaigns, giving contributions to candidates, and manipulating public opinion (DeLord, Burpo, and Shannon 2008). Second, as American history shows (Skocpol 2003), long-standing fraternal associations have effected substantial political change through mass mobilization, as do contemporary membership organizations such as the National Rifle Association (NRA), an FOP ally (Grimaldi and Horwitz 2010).

Moreover, unions influence political participation beyond their membership through social networks (Ahlquist, Clayton, and Levi 2014). As a federated organization, the FOP may be suited for collective action (Becher, Stegmueller, and Käppner, 2018). Furthermore, police officers have high levels of in-group solidarity, often called "police culture," which forms from the shared and stressful experience of police work (Loftus 2010). Thus, their networks may be especially potent. In 2016, many the 2016 election. Then, I estimated the effect of the endorsement on county-level election results using a difference-in-differences regression, modeling changes in Republican vote shares from 2012 to 2016 as a function of FOP presence, net of other factors.

\section{Political Activism by Law Enforcement}

I tested how the 2016 election activated and mobilized police using the Cooperative Congressional Election Survey (CCES), comparing changes in political behavior among police officers in 2016 and 2012 to changes among the voting-eligible public. Police were identified in the 2016 CCES using string matching of self-reported occupations; in the 2012 CCES, they were identified as those reporting to be working in "protective services" and for county or local government. This process identified 243 police officers in 2012 and 109 in 2016.

Police officers were highly engaged in 2016, as shown in table 2. Fully $69 \%$ of police officers reported that they were contacted by a campaign, compared to $44 \%$ of the general population. Of those reporting, $10 \%$ stated that they volunteered for a campaign or candidate and $36 \%$ contributed funds to a campaign; each behavior occurred at about twice the rate of the general population. Moreover, police officers became more politically engaged in 2016 than in 2012. Comparing the change in behavior between officers in 2016 and 2012 to the change among the public, officers were more likely (i.e., $\mathrm{p}<0.05$ ) to report that they were contacted by a campaign, voted GOP for president, volunteered for a campaign, and contributed to a campaign.

\section{Difference in Differences in GOP Vote Share}

Following a wealth of literature in political science that examines the number of local associations per person as a measure of organizational presence in a community (see the appendix), I used FOP per capita lodge density to assess FOP strength and its relationship to the vote shift to Trump. The results of four OLS regression models evaluating this relationship between FOP lodge density and vote shift toward Trump are shown in table 3 . That is, the model compares the GOP vote share among counties of varying FOP presence across two presidential election cycles, after controlling for plausible confounders including racial and economic characteristics, percentage of county employment in protective services, and percentage of veterans. For additional details about data sources, control variables, and descriptive statistics, see the supplementary appendix. 
Table 2

FOP Strength and $\Delta$ GOP Vote Share

(1)

(2)

(3)

(4)

\begin{tabular}{|c|c|c|c|c|}
\hline & & & & \\
\hline Lodge Density & $1.436 * * *(0.15)$ & $1.585^{* * *}(0.13)$ & $0.402^{* * *}(0.11)$ & $0.890 * * *(0.23)$ \\
\hline Blue Collar \% & & & $-0.004(0.01)$ & $-0.011^{* * *}(0.02)$ \\
\hline Protective \% & & & $-0.038(0.05)$ & $-0.031(0.07)$ \\
\hline Union Density & & & $-0.047(0.11)$ & $-0.167(0.22)$ \\
\hline \multirow[t]{2}{*}{ Associational Density } & & & -0.148 & -0.186 \\
\hline & & & $(0.09)$ & $(0.17)$ \\
\hline White No College \% & & & $0.282^{* * *}(0.01)$ & $0.273^{* * *}(0.02)$ \\
\hline Manufacturing LQ & & & $0.036 * *(0.01)$ & $0.410 * *(0.16)$ \\
\hline \multirow[t]{2}{*}{ Mining LQ } & & & 0.006 & $0.024 * *$ \\
\hline & & & $(0.01)$ & $(0.01)$ \\
\hline Farming LQ & & & $-0.008(0.01)$ & $-0.010(0.02)$ \\
\hline \multirow[t]{2}{*}{ Manufacturing LQ Trend } & & & 0.043 & -0.394 \\
\hline & & & $(0.12)$ & $(0.20)$ \\
\hline \multirow[t]{2}{*}{ Mining LQ Trend } & & & -0.004 & -0.024 \\
\hline & & & $(0.01)$ & $(0.02)$ \\
\hline Farming LQ Trend & & & $0.019(0.02)$ & $0.018(0.04)$ \\
\hline White \% & & & $-0.004(0.01)$ & $-0.027^{* *}(0.01)$ \\
\hline Rural & & & $0.290 * * *(0.03)$ & $0.580 * * *(0.05)$ \\
\hline Veteran \% & & & $0.001(0.02)$ & $0.065(0.04)$ \\
\hline Hispanic \% & & & $-0.002(0.01)$ & $-0.014(0.01)$ \\
\hline \multirow[t]{2}{*}{ Poverty \% } & & & -0.027 & $-0.111^{* *}$ \\
\hline & & & $(0.02)$ & $(0.04)$ \\
\hline \multirow[t]{2}{*}{ Income } & & & -0.013 & -0.046 \\
\hline & & & $(0.01)$ & $(0.02)$ \\
\hline GOP $\triangle 2012$ & & & $-0.035(0.03)$ & $0.037(0.05)$ \\
\hline Observations & 3,110 & 3,110 & 3,110 & 3,110 \\
\hline Adjusted $R^{2}$ & 0.03 & 0.45 & 0.69 & 0.79 \\
\hline State Trend & . & Yes & Yes & Yes \\
\hline Population Weights & . & & & Yes \\
\hline
\end{tabular}

Across various specifications-and holding constant other factors that explain Trump's appeal-a significant and important association persists between the density of FOP lodges and the vote shift for Trump. In table 3, model 1 shows an association between lodge density and vote shift without covariates, model 2 adds state-trend dummies, and model 3 adds county-level covariates. The complete model 4 , which includes population weights, indicates that a one-unit increase in lodge density is associated with a 0.9-percentage-point swing from Romney to Trump.

Assuming that this regression coefficient was causal and uniform across counties, I used it to calculate the counterfactual vote share that Trump would have received in each county without FOP support. The lodge density in each county multiplied by $\beta$ provided the estimated change in vote share attributable to the FOP. Multiplying this quantity by the total number of votes in the county and aggregating this number of county-level votes attributable to the FOP to the state level provided a "back-of-the-envelope" indication of the counterfactual electoral map. In Michigan, the model implied a GOP two-party vote swing of 0.3 percentage points, or about 15,400 votes, attributable to the FOP-a quantity that exceeds the number of votes by which Trump won the state. In Pennsylvania, birthplace of the FOP, the associated swing was 0.7 percentage points, or about 31,800 votes. The supplementary appendix further discusses the procedures used to estimate and interpret the effect size.

\section{LAW AND ORGANIZATIONS IN 2016}

Trump's win in November 2016 was so surprising to most scholars and pundits that their retrospective accounts stressed unique events and media celebrity. Organizational factors received hardly any attention. However, this article uses evidence from campaign events, data on police political behavior, and vote shares to make the case that widespread organizational networks may have been critical. Trump 2016 improved on Romney 2012 in places of FOP strength. 
Table 3

Political Behavior among Police Officers

\begin{tabular}{|c|c|c|c|c|c|c|}
\hline & Pop. Mean (12) & "Police" Mean (12) & Pop. Mean (16) & Police Mean (16) & Did & $p$-value \\
\hline Contacted by Campaign & 0.58 & 0.63 & 0.44 & 0.69 & 0.20 & 0.00 \\
\hline Vote GOP Pres. & 0.38 & 0.53 & 0.30 & 0.68 & 0.23 & 0.00 \\
\hline Definitely Vote & 0.73 & 0.80 & 0.77 & 0.91 & 0.06 & 0.10 \\
\hline Political Sign & 0.20 & 0.23 & 0.13 & 0.25 & 0.08 & 0.10 \\
\hline Volunteer & 0.08 & 0.06 & 0.05 & 0.10 & 0.07 & 0.03 \\
\hline Matched Voter File & 0.83 & 0.86 & 0.66 & 0.81 & 0.12 & 0.01 \\
\hline Contribute & 0.26 & 0.28 & 0.19 & 0.36 & 0.15 & 0.01 \\
\hline
\end{tabular}

Available data and the FOP's non-endorsement in 2012 allowed me to probe this particular organization. However, other networks likely weighed in for Trump, including the NRA, Americans for Prosperity, and evangelical churches. For now, these results underscore the value of this line of research. For presidential contests especially, widely connected organizational networks can be built (e.g., in the 2008 Obama campaign) or borrowed (e.g., in the 2016 Trump campaign). However, they are unlikely to be irrelevant. For Trump in 2016, blue endorsements mattered precisely because police are so widely organized across communities. When hundreds of thousands of men and women in blue proclaimed Trump their candidate, many other Americans got the message.

\section{SUPPLEMENTARY MATERIAL}

To view supplementary material for this article, please visit https://doi.org/10.1017/S1049096518001841

\section{REFERENCES}

Ahlquist, John S., Amanda B. Clayton, and Margaret Levi. 2014. "Provoking Preferences: Unionization, Trade Policy, and the ILWU Puzzle." International Organization 68 (1): 33-75.

Arnesen, Eric, and Joseph Lipari. 2007. Encyclopedia of US Labor and Working-Class History, Vol. 1. Abingdon, England: Taylor \& Francis.

Associated Press. 2016. "Trump Gets Some Target Practice during Iredell County Stop.” AP News, August 18. Available at www.apnews. com/5ed9b572b89b4935868fcfc50a88c271.

Becher, Michael, Daniel Stegmueller, and Konstantin Käppner. 2018. "Local Union Organization and Law Making in the US Congress." Journal of Politics 80 (2): 539-54.

Buffer, Michael. 2016. “Trump Dominates in Luzerne County.” The Citizens Voice, November 10. Available at www.citizensvoice.com/news/trump-dominates-inluzerne-county-1.2115768.

Butler, Paul. 2017. "Why the Fraternal Order of Police Must Go." The Marshall Project, October 11. Available at www.themarshallproject.org/2017/10/11/whythe-fraternal-order-of-police-must-go.

Charles, J. Brian. 2017. "Justice Department Ends Era of Pushing Police Reform." Governing Magazine, September 18. Available at www.governing.com/topics/publicjustice-safety/lc-sessions-justice-police-reforms-trump-doj-milwaukee.html.

Connors, Emma. 2016. “Clinton in Ohio: All Red with One Blue Spot.” Lowy Institute, November 16. Available at www.lowyinstitute.org/the-interpreter/clinton-ohioall-red-one-blue-spot.

Delgadillo, Natalie. 2017. "Sessions' New Order Lets Police Circumvent State Laws on Civil Asset Forfeiture." Governing Magazine, July 19. Available at www. governing.com/topics/public-justice-safety/gov-civil-asset-forfeiture-directivejeff-sessions-police.html.

DeLord, Ron, Jon Burpo, and Michael R. Shannon. 2008. Police Union Power, Politics, and Confrontation in the 21st Century: New Challenges, New Issues. Springfield, IL: Charles C. Thomas Publisher.
Fraternal Order of Police. 2004. "F.O.P.: Putting Words into Action in Support of the President!" Grand Lodge FOP, October 14. Available at https://web.archive. org/web/20041208070242.

Fraternal Order of Police. 2013. "H.R. 218, the Law Enforcement Officers' Safety Act." Grand Lodge FOP (no date). Available at www.fop.net/legislative/issues/ hr218/hr218faq.pdf.

Gaines, Larry and John Worrall. 2011. Police Administration. Clifton Park, NY: Cengage Learning.

Gallek, Ed. 2016. "Internal Review after Police Union Leader Attends Trump Rally in Uniform." Fox8, October 11. Available at https://fox8.com/2016/10/11/i-teaminternal-review-after-police-union-leader-attends-trump-rally.

Gardiner, Dustin. 2016. "Phoenix Demands Trump Campaign Pull Ad with City Police Officers.” The Republic, September 19. Available at www.azcentral.com/ story/news/local/phoenix/2016/o9/29/phoenix-demands-trump-campaign-pullad-over-depiction-officers/91300312.

Giordano, Dom. 2016. "Philly FOP Chief on Presidential Endorsement." CBS Philly, September 19. Available at https://philadelphia.cbslocal.com/2016/09/19/phillyfop-chief-on-presidential-endorsment-clinton-blew-the-police-off.

Glunt, Nick. 2016. "Sheriff Steve Barry's Photo with Donald Trump Draws Criticism, Concerns of Racial Disparities.” Akron Beacon Journal, October 10. Available at www.ohio.com/news/local/sheriff-steve-barry-s-photo-with-donaldtrump-draws-criticism-concerns-of-racial-disparities-1.718291.

Griffith, David. 2016. "President Trump and Police." Police Magazine, December 8 Available at www.policemag.com/channel/patrol/articles/2016/12/presidenttrump-and-police.aspx.

Grimaldi, James V., and Sari Horwitz. 2010. "James Pasco, Fraternal Order of Police Lobbyist, Influences Gun Debate and More.” Washington Post, December 15. Available at www.washingtonpost.com/wp-dyn/content/article/2010/12/14/ AR2010121406068.html.

Hawkins, Derek. 2016. "San Antonio Cops Face Discipline for Wearing 'Make America Great Again' Hats in Trump Video." Washington Post, October 12. Available at www.washingtonpost.com/news/morning-mix/wp/2016/10/12/san-antonio-copsface-discipline-for-wearing-make-america-great-again-hats-in-trump-video.

Hensch, Mark. 2017. “Sessions to DOJ: Review Police Reform Pacts.” The Hill, April 3. Available at https://thehill.com/homenews/administration/327127sessions-to-doj-review-police-reform-pacts.

Huq, Aziz Z., and Richard H. McAdams. 2016. "Litigating the Blue Wall of Silence: How to Challenge the Police Privilege to Delay Investigation." University of Chicago Legal Forum: 213.

Kamisar, Ben. 2016. "Nation's Largest Police Union Endorses Trump.” The Hill, September 16. Available at https://thehill.com/blogs/ballot-box/presidentialraces/296342-nations-largest-police-union-endorses-trump.

Kaste, Martin. 2016. "What Trump's Election Means to Police-and Police Reform." National Public Radio, November 10. Available at www.npr.org/2016/11/10/ 501613514/many-police-across-the-country-feel-emboldened-by-trumps-victory.

Lee, Kurtis. 2016a. "Campaign 2016 Updates: Donald Trump Concedes Obama Was Born in U.S. after Years of Stoking Conspiracy Theory." LA Times, September 16. Available at www.latimes.com/politics/la-na-pol-trumpobama-birth-20160916-snap-story.html.

Lee, Kurtis. 2016b. “Campaign 2016 Updates: 'We Don't Operate on Innuendo,' Obama Says of FBI Investigation into Newfound Emails." LA Times, November 2. Available at www.latimes.com/nation/politics/trailguide/la-na-trailguideupdates-11022016-htmlstory.html.

Leighley, Jan E., and Jonathan Nagler. 2007. "Unions, Voter Turnout, and Class Bias in the US Electorate, 1964-2004." Journal of Politics 69 (2): 430-41. 
Lesher, Stephan. 1994. George Wallace: American Populist. New York: Da Capo Press.

Lipset, Seymour Martin. 1972. "The Politics of the Police." Reading in Race and Ethnic Relations: The Commonwealth and International Library. Reading in Sociology: 280 .

Livingston, Doug, and Theresa Cottom. 2016. "Trump's Day in Akron: Early Bird Catches Crowd off Guard." Akron Beacon Journal, August 22. Available at ohio. com/akron/news/trump-s-day-in-akron-early-bird-catches-crowd-off-guard.

Loftus, Bethan. 2010. "Police Occupational Culture: Classic Themes, Altered Times." Policing \& Society 20 (1): 1-20.

Love, David. 2017. "Does the Fraternal Order of Police Have A Black People Problem?" Atlanta Black Star, September 7. Available at https://atlantablackstar. com/2017/09/o7/fraternal-order-police-black-people-problem.

Lucas, Ryan. 2017. “Trump Administration Lifts Limits on Military Hardware for Police." National Public Radio, August 18. Available at www.npr. org/2017/o8/28/546743742/trump-administration-lifts-limits-on-militaryhardware-for-police.

Macgillis, Alec. 2012. "The Battleground.” New Republic, May 18. Available at https://newrepublic.com/article/103409/ohio-battleground-state-election-2012labor-union-sb5-sherrod-brown-john-kasich.

Martin, Rachel. 2016. “The Nation's Largest Police Union Endorses Donald Trump." National Public Radio, September 16. Available at https://thehill.com/ blogs/ballot-box/presidential-races/296342-nations-largest-police-unionendorses-trump

McPhee, Michele. 2016. "The Hidden Trump Voter: The Police." Boston Globe, November 9. Available at www.bostonglobe.com/opinion/2016/11/o9/thehidden-trump-voter-police/71MUxHoqBzNCKZZcpH42nO/story.html.

Potomac Local. 2016. "Stafford Sheriff David Decatur Hosts Trump ClosedDoor Meeting." Potomac Local, October 19. Available at https://potomaclocal. com/2016/o8/21/stafford-sheriff-david-decatur-hosts-trump-closed-doormeeting.

Rentz, Catherine. 2016. "Maryland Police Stood Apart from Others in 'No Endorsement' of Trump." Baltimore Sun, October 15. Available at www.baltimoresun.com/news/maryland/politics/bs-md-sun-investigatesfop-trump-20161015-story.html.
Schneider, Sarah. 2016. "Pittsburgh Police Union Part of Vote to Endorse Trump." Radio Station WESA, September 21. Available at www.wesa.fm/post/pittsburgh police-union-part-vote-endorse-trump\#stream.

Schreckinger, Ben. 2015. "The Secret Weapon for America's Beleaguered Police." Politico, May 9. Available at www.politico.com/story/2015/05/the-secret-weaponfor-police-117779.

Siemaszko, Corky. 2016. "Black Cops at Odds with Fraternal Order of Police over Trump Endorsement.” NBC News, September 22. Available at www. nbcnews.com/news/us-news/black-cops-odds-fraternal-order-police-overtrump-endorsement-n652071.

Skocpol, Theda. 2003. Diminished Democracy: From Membership to Management in American Civic Life, Vol. 8. Norman: University of Oklahoma Press.

Swaine, Jon, and George Joseph. 2016. "Hackers Post Private Files of America's Biggest Police Union.” The Guardian, January 18. Available at www.theguardian. com/uk-news/2016/jan/28/fraternal-order-of-police-hacked-fbi-investigationdata-servers.

Swan, Jonathan. 2016. "Police Union: Clinton Snubbed Us." The Hill, August 6. Available at https://thehill.com/blogs/ballot-box/presidential-races/290586police-union-clinton-snubbed-us.

Swicegood, Donna. 2016. "Iredell Sheriff Recalls Trump's Surprise Visit.” Statesville Record \& Landmark, September 16. Available at www.statesville.com/news/ iredell-sheriff-recalls-trump-s-surprise-visit/article_14ao82d4-746o-11e6-8565o7740544199d.html.

Torry, Jack. 2012. "Ohio Police Union Backs Brown in Senate Race." Columbia Dispatch, July 18. Available at www.dispatch.com/article/20120718/ NEWS/307189843.

Walsh, Justin E. 1977. The Fraternal Order of Police, 1915-1976: A History. Paducah, KY: Turner Publishing Company.

Whack, Errin, and Sadie Gurman. 2017. "Civil Rights Groups Alarmed over Retrea on Police Reforms." Chicago Tribune, April 4. Available at www.chicagotribune.com/ news/nationworld/ct-civil-rights-groups-police-reforms-20170404-story.html.

Wheaton, Sarah. 2016. "Police Union Meets with Trump as it Weighs Endorsement." Politico, August 5. Available at www.politico.com/story/2016/o8/trump-fraternalorder-of-police-226717. 